
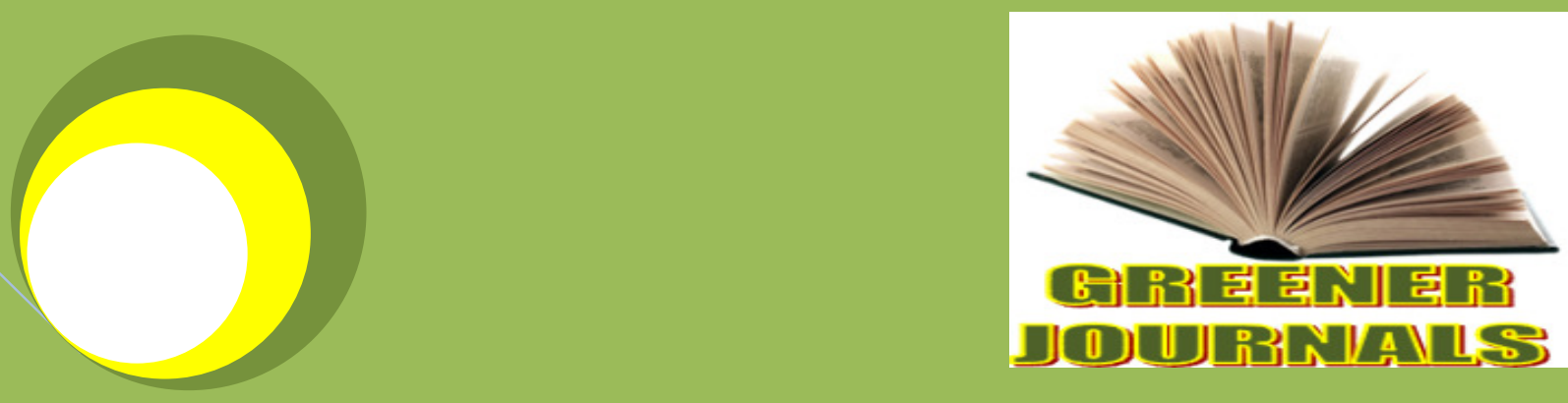

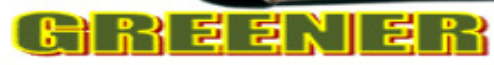

D(0) $(1)$ D

Gieeneri loutral of Pl Pant Breeding and Cron Science ISSN: 2354-2292

Genotype - Environment Interaction for Plant

Development and Some Yield Components in

Common Bean (Phaseolus vulgaris L.) during the 2012 Wet Season

By

Nwadike Christopher Vange Terkimbi Ochigbo A.E. 


\title{
Genotype - Environment Interaction for Plant Development and Some Yield Components in Common Bean (Phaseolus vulgaris L.) during the 2012 Wet Season
}

\author{
*Nwadike Christopher, Vange Terkimbi and Ochigbo A.E.
}

\author{
Department of Plant Breeding and Seed Science, University of Agriculture, Makurdi, Nigeria. \\ ${ }^{*}$ Corresponding Author's Email: chrisnwadike@ymail.com
}

\begin{abstract}
A multi- location field trial was conducted at two location to estimate genotype by environment interaction for growth, yield and yield characters in nine accession lines of common bean Phaseolus vulgaris L. A randomised complete block design with three replication was use for the field trials. A highly significant differences among the tested genotypes in the two environments were detected for Leaf count, Days after Sowing to first flowering, Days after Sowing to $50 \%$ flowering, Plant height at $50 \%$ flowering, Pod count per plant, Pod length per plant, Seed diameter per pod, Seed count per pod, Pod yield per plot, Seed yield per plot and Dry matter weight among the testes accessions. The genotype and environment interaction exhibited significance for some characters suggests that genotypes interacted considerably with the environments in the expression of characters, and will behave differently under different environment. A wide mean range of variation was detected which reflects the extent of phenotypic variability in respect of the characters and a good scope for selection of suitable basic material for plant breeders for further crop improvement. Further multi-location trial for seasons should be carried out for the proper selection of the desired genotype.
\end{abstract}

Key words: Germplasm, environment interaction, selection, common bean, Genetic parameter, Variation.

\section{INTRODUCTON}

The performance of a crop variety is the resultant effect of its genotype and the environment in which it is grown. The term genotype-environment (GE) interaction is used to indicate inconsistency in the performance of genotypes or a change in the magnitude of the difference between genotypes under a range of environments. GE interactions are of major importance to the plant breeder in developing improved cultivars (Asuman et al., 2010; Elsiddig et al., 2003; Park,1987). The influence of GE interactions on crops when tested over a range of environments was well recognized by the early pioneers of crop science such as Johannsen. He stated "that genes are not responsible for personal endowments of an individual, the environment also has part to play in determining the life situation." (Thurling, and Vijendra Das, 1979; Vijendra Das, 2000). Hence, any breeding programme aiming at increasing yield should consider association between yield and its attributes through estimation of influence of environmental factors on the expression of some key characters, as indicated by environmental variances as compared to its genotypic variances which help a great deal in formulating selection indices to aid plant breeders operate selection programmes efficiently.

Of all crop species, leguminous plants are found throughout the world ,but the greatest diversity have been known to occur in the tropic and sub-tropical ecology, with thousands of promising species awaiting research and study. Norman et al.(1995), reported that of all edible legumes, Phaseolus vulgaris L. have the widest geographical distribution and an important food source worldwide. The green immature pods of some varieties may be cooked and eaten as vegetable while the seeds of other varieties are harvested at a later growth stage and consumed for their high protein content ( Adesoye and Ojobo, 2012 ; Salehi et al., 2008), while the leaf is occasionally used as vegetable and the straw as fodder. Consumption of $P$. vulgaris has been linked to several health benefits such as reduction of cholesterol level (Rosa et al., 1998), reduction of coronary heart diseases (Anderson et al., 1998; Bazzano et al., 2001), favourable effects against cancer (Hangen and Bennick, 2002), decreasing diabetes and obesity (Geil and Anderson, 1994) and high antioxidant capacity (Heimler et al., 2005). However, the consumption of $P$. vulgaris is limited due to the presence of certain anti-nutritional components such as phytic acid, flatulence factors, saponins, lectins and the need for prolonged cooking (Lyimo et al., 1992). Phaseolus vulgaris L. present an opportunity to plant breeder to explore the available genetic resources locked in the diversity and variability available in our land races to develop adaptable cultivar that would be among 
elite crop varieties suitable for wider cultivation and acceptability for its nutritive and organoleptic values (Sadeghi et al., 2011). This existing genetic diversity makes them a valuable resource and potential donors of genes for breeding purposes, diversification of production, developing new farming systems and generates the much needing baseline data to guide selection of parental lines and design of breeding scheme (Soleri and Smith 1995; Jing et al., 2010). It is essential to know the relationship between yield and its component traits and how these characters are associated in their interaction under a wide range of environment (Assady et al., 2005).

Studies have showed that major production constraint to common bean in growing areas are diseases and pests, especially fungal pathogens, drought, heat, $\mathrm{P}$ and $\mathrm{N}$ deficiency and use of traditional landrace varieties, average yield from farmers field are very low as compared to the $729 \mathrm{~kg} / \mathrm{ha}$ in 2008 of estimated average world yield (Hala et al., 2011; Beebe et al., 2011a; Wortmann et al., 1998). Common bean ( phaseolus vulgaris $L$ ) research in terms of crop improvement is still at it lowest level in Nigeria. In order to incorporate the desired characters in a cultivar, the breeder has to consider the performance of these characters with respect to environmental interaction and test the genotypes accordingly at more than one location to study their stability for these desired characters. The present study objective was initiated to bridge the existing gaps in literature of common bean research and aimed at studying $G \times E$ interactions of nine potentially promising common beans germplasm evaluated under a range of contrasting agro ecological zone.

\section{MATERIALS AND METHODS}

A total of nine landraces of $P$. vulgaris $L$ were collected accros two nearby farming location of Mangu Local Government Areas (LGA) on long.9 $9^{\circ} 2^{\prime} \mathrm{N}$, lat. $9^{\circ} 0^{\prime} \mathrm{E}$. altitude $1134 \mathrm{~m}$ (Bakin wake, Kwakil, Jan wake,Ngogot,Dan gora) and Bokkos Local Government Areas (LGA) on long. $9^{\circ} 17^{\prime} \mathrm{N}, 8^{\circ} 59^{\prime} \mathrm{E}$. altitude $1334 \mathrm{~m}$ (Chanlet, Dan baga, Ambul-1,Ambul-2), of Plateau State, all within the mid-altitude agroecological zone. The seeds were cleaned of debris, stones, shafts and straws and subjected to floatation process in which $2 \mathrm{~kg}$ of cleaned seeds were added to a transparent bowl containing 10 litres of distilled water. The seeds were separated based on density profile of the seeds. Healthy and viable seeds settled towards the bottom of the beaker while damaged insect perforated seeds and other light weight impurities found floating was discarded. Seed recovery was done using the aluminum screening mesh size bowl to separate and discard the liquid portion. The seeds were spread on nine separate laboratory trays for each accession type and left to dry under the ambient room temperature (tempering) for 2days.

The experiments was conducted during 2012 wet cropping seasons at the experimental, teaching and research farm of the University of Agriculture, Makurdi ( 07:41oN, 08:37E, Altitude 106.4m) and at the teaching and research field of the Forestry Research Institute of Nigeria (FRIN), Federal College of Forestry, Jos Plateau State $\left(09^{\circ} 56^{\prime} \mathrm{N}, 08^{\circ} 53^{\prime} \mathrm{E}\right.$ altitude of $1,217 \mathrm{M}$ ) within the Southern and Northern Guinea Savanna ecological zone of Nigeria (Kowal and Knabe, 1972). A Randomized Complete Block Design (RCBD) with three block and nine genotypes were used.The land preparationwere carried out manually and began by clearing the plot of land previously under fallow at the various experimental locations. The experimental gross plot size of $140.4 \mathrm{~m}^{2}(23.4 \mathrm{~m}$ $x 6 \mathrm{~m}$ ) were used. The required areas were marked out and made into nine subplot of bed raised about $25 \mathrm{~cm}$ from the ground using a hoe, and measured $1.8 \mathrm{~m}$ long and $1.2 \mathrm{~m}$ wide in each block. $0.6 \mathrm{~m}$ spaced boarders were maintained for each subplot per block respectively. The seeds were treated with a fungicide Apron-plus as recommended by ICS-Nigeria (2010), at recommended rate and sown on the $1^{\text {st }}$ May 2012 at the Jos experimental plot and on the $5^{\text {th }}$ June at the Makurdi experimental plot respectively. Four seeds were sown per planting hole at spacing of $45 \mathrm{~cm} \times 60 \mathrm{~cm}$ and plan were thinned to one plant per stand after germination at 2WAS (Weeks After Sowing) and gave a total of 12 plant stand per plot of 3 rows of 4 plant per row and a total of $55,555.55$ plant population per ha respectively. NPK 15-15-15 inorganic fertilizer were applied at the rate of $100 \mathrm{~kg} / \mathrm{ha}$ as a starter dose to the crop at the determined quantity of $0.13 \mathrm{~g}$ per plot, at 2WAS after thinning operation while single super phosphate $\left(18 \% \mathrm{P}_{2} \mathrm{O}_{5}\right)$, were applied at the rate of $30 \mathrm{~kg} / \mathrm{ha}$ according to ICSNigeria (2010), at the determined quantity of $36 \mathrm{~g}$ per plot, according to Avav and Ayuba (2006), at the 4,6 and 8 WAS respectively. The Insect pests were controlled by the combined application of insecticides: ( Cypermethrin plus Dimethoate ) Best Action and ( Lamda cyhalothrine $25 \mathrm{EC}$ ) Karate $2.5 \mathrm{EC}$, at the recommended application rates of $1 \mathrm{~L} / \mathrm{ha}$, using $75 \mathrm{~mL}$ in $15-\mathrm{L}$ knapsack sprayer and $0.8 \mathrm{~L} / \mathrm{ha}$, using $40 \mathrm{~mL}$ in $15-\mathrm{L}$ knapsack sprayer respectively according to Avav and Ayuba (2006), which started at 2WAS and were continued at weekly interval from the sixth week after sowing until harvest. Adequate farm sanitation was maintained by manual weeding regularly at two, four and six weeks interval, using a hoe and complemented by hand pulling as the weeds appeared until the crops were harvested respectively.

\section{Data collection and analysis}

To eliminate the border effect between the plots, observations were recorded on five (5) randomly selected plants per plots and evaluated on the basis of morpho-agronomic traits as described and Data analysis were carried out using Genstat 7.1 version (2003) and SPSS, version 16.0 (2007). 
1. Germination count $(\mathrm{GC})$ : This was determined after twelve days of sowing, number of seedlings that emerged in each plot were counted and recorded.

2. Plant Height (PHT) : This was obtained by measuring the heights of five sampled plants in each sub plot from the base of the plant to the terminal point using a ruler. All the measurements from the sampled plants were added together and divided by the total number of plants. This was expressed as the mean plant height in centimeter $(\mathrm{cm})$.

3. Plant Stem Girth (PSG): This was determined by wounding a thread round the plant and placing the thread on a graduated meter rule to take the reading and obtain the circumference. All measurement were added together and divided by the total number of plants measured and recorded in centimeter $(\mathrm{cm})$.

4. Number of leaves per plant (NOL): This was done by counting and adding together the number of leaves on the sampled plants and divided by the total number of plant. This was determined at intervals of two weeks from the date of sowing to the time of attaining $50 \%$ flowering.

5. Number of primary branches (NOB): The number of primary branches was obtained by counting all the primary branches arising from the main stem on every sampled plant. All the counts were added together and divided by the number of plant sampled and expressed in numbers.

6. Days to first flowering (DFF): This was determined by counting the days from sowing to when one flower opened in each subplot.

7. Days to fist pod maturity (DFPM): This was determined by counting the number of days from sowing to when the first pod attains full physiological maturity.

8. Days to $50 \%$ flowering (D50\%F): This was determine by counting the number of days from sowing to when half of the plant population per sub plant had flowered.

9. Plant Height at 50\% flowering (PHT@50\%): This was obtained by measuring the height of sampled plants in each sub plot, when $50 \%$ of the plant has flowered, the measurement was carried out from the base of the plant to the terminal point using a ruler. The values obtained were added together and divided by the total number of plants and expressed as the mean plant height in centimeter $(\mathrm{cm})$.

10. Number of Pod Produce per Plants (NOP): This was determined by counting and adding all together the number of pods on each sampled plant and dividing by the total number of plant.

11. Pod length (PDLGHT): This was determined by adding together the length of ten (10) randomly selected pod from the harvested sampled plant and divided by the total number of pods. The measurement was made with centimeter using a meter rule.

12. Pod diameter (PDDDIA): This was determined by adding together the width of ten (10) randomly selected pods from the harvested sampled plant and dividing by the total number of pods. The measurement was made in centimeter using a meter rule.

13. Seed length (SDLGHT): This was determined by adding together the length of ten (10) randomly selected seeds from the harvested sampled plants and divided by the total number of seeds. The measurement was made in centimeter using a micro-meter screed gauge.

14. Seed Diameter (SDDIA):This was determined by adding together the width of ten (10) randomly selected seeds from the harvested sampled plants and divided by the total number of seeds. The measurement was made in centimeter using a micrometer screw gauge.

15. Number of Seed Per Pod (SDNOP) : This was determined by adding together the number of seed of ten (10) pod randomly selected from pod harvested from sampled plants and divided by the total number of pod express in numbers.

16. 100 Seed weight (100-SDWT): This was determined by measuring the weight of 100 seeds harvested from the sampled plants per plot in randomized procedure and expressed in grams (g).

17. Mass of Dry Matter Yield) (MDMY): This was determine by weighing of leaves, twigs and parts of roots of all plant after harvesting completely from each plot express in $\mathrm{kg} / \mathrm{ha}$.

18. Plant count at harvest (NP@HST) : The plant population at harvest in each plot were counted and expressed in numbers.

19. Computed pod (PDYLDPLT) and seed yield (SDYLDPLT) per plot expressed in yield/ha: pod and seed yield for the various accessions lines was estimated in kilogram per hectare (or $\mathrm{kg} / \mathrm{ha}$ ) by obtaining the total pod and seed yield for each accessions by dividing the plot yield $\left(\mathbf{X}_{\mathrm{ij}}\right)$ by the plot area $\left(\mathbf{Y}_{\mathrm{ij}}\right)$ harvested and multiplied by

$$
\frac{10,000 \mathrm{~m}^{2}}{1000}
$$

The total pod andseed yield per plot expressed in $\mathrm{kg} / \mathrm{ha}$

$$
\underline{\mathrm{Y}}_{\mathrm{ij}-} \times \frac{10,000 \mathrm{~m}^{2}}{1000}
$$


Where;
$\mathbf{X} \mathbf{i j}=$ the yield of the ith genotype in the jth block.
$\mathbf{Y i j}=$ the area of the ith plot in the jth block

\section{RESULTS}

\section{Genotype and environment (location) interaction.}

The Genotype and environment (location) interaction results are presented in Table 1. In this study, the combined analysis of variance (ANOVA) revealed that a High significant variation was present among the genotypes except for plant collar girth. Leaf count, days after sowing to 50\% flowering, plant height at $50 \%$ flowering, pod diameter and seed length showed no significant difference for location. The genotype and location interaction exhibited high significance for all the characters except collar girth, days to first pod maturity, pod diameter, seed length, number of plant count at harvest, 100 seed weight and weight of dry matter respectively. The result suggests that the genotypes interacted considerably with the location in the expression of the characters and behaved differently under varying environment.

Table 1: Mean square from analysis of variance for growth and some yield contributing characters of Phaseolus vulgaris L. during the 2012 wet season.

\begin{tabular}{|c|c|c|c|c|}
\hline \multirow[b]{2}{*}{ Character } & \multicolumn{2}{|c|}{ Sources of variation } & \multirow[b]{2}{*}{$\begin{array}{l}\mathrm{G} \times E \\
(\mathrm{df}=8)\end{array}$} & \multirow[b]{2}{*}{$\frac{\text { Error }}{(\mathrm{df}=34)}$} \\
\hline & $\frac{\text { Genotype }}{(\mathrm{df}=8)}$ & $\frac{\text { Environment }}{(\mathrm{df}=1)}$ & & \\
\hline Germination count(GC) & $15.21^{*}$ & $9.80^{*}$ & 0.80 & 0.31 \\
\hline Leaf count(NOL) & $163.00^{*}$ & $69.36^{*}$ & $34.40^{*}$ & 2.88 \\
\hline Branch count(NOB) & $9.27^{*}$ & 2.20 & 1.96 & 1.43 \\
\hline Plant height(PHT) & 2091.3 & 2396 & 2077.1 & 1805 \\
\hline Collar girth(PSG) & $0.96^{\star}$ & 0.25 & 0.17 & 0.10 \\
\hline Days to first flowering(DFF) & $155.82^{*}$ & $24.00^{*}$ & $26.75^{\star}$ & 3.06 \\
\hline Days to $50 \%$ flowering(D50\%F) & $98.13^{\star}$ & $40.91^{*}$ & $34.24^{*}$ & 7.14 \\
\hline $\begin{array}{l}\text { Plant height at } 50 \% \text { flowering } \\
\text { (PTH@50\%F) }\end{array}$ & $3826.00^{*}$ & 73.70 & $114.00^{*}$ & 31.60 \\
\hline Days to first pod maturity(DFPM) & $96.25^{\star}$ & $48.17^{\star}$ & 35.00 & 21.82 \\
\hline Peduncle count(PDCT) & $81.89^{*}$ & $156.74^{*}$ & $27.45^{\star}$ & 9.73 \\
\hline Pod count per plant(NOP) & $211.56^{\star}$ & $9974.24^{*}$ & $202.47^{\star}$ & 14.78 \\
\hline Pod diameter per plant(PDDIA) & $0.08^{*}$ & 0.00 & 0.01 & 0.02 \\
\hline Pod length per plant(PDLGHT) & $11.28^{*}$ & $17.23^{*}$ & $1.28^{*}$ & 0.22 \\
\hline Seed length per pod(SDLGHT) & $0.20^{*}$ & $0.22^{*}$ & 0.03 & 0.05 \\
\hline Plant count at harvest(NP@HST) & $16.14^{*}$ & $160.17^{*}$ & $3.13^{*}$ & 2.59 \\
\hline Seed diameter per pod(SDDIA) & $0.12^{*}$ & $0.07^{*}$ & $0.02^{*}$ & 0.00 \\
\hline Seed count per Pod(SDNOP) & $6.63^{\star}$ & $2.41^{*}$ & $0.64^{*}$ & 0.07 \\
\hline Pod yield per plot(PDYLDPLT) & $2021047^{*}$ & $1954471^{*}$ & $361445.9^{*}$ & 80506.6 \\
\hline Seed yield per plot(SDYLDPLT) & $1701166.4^{*}$ & $13704771.7^{*}$ & $236683^{*}$ & 40872 \\
\hline 100 - seed weight(100-SDWT) & $363.53 .4^{*}$ & $60.17^{*}$ & 8.04 & 5.53 \\
\hline Dry Matter Weight(DMYLD) & $1898491^{*}$ & $27042774^{*}$ & $650102.2^{*}$ & 221005 \\
\hline
\end{tabular}

\section{Mean range Variation}

In the present study the accessions exhibited considerable amount of variation in the characters evaluated. The mean range of variation reflects the extent of phenotypic variability in respect of the characters, includes genotypic, environmental and genotype environmental interaction components. The genotypes exhibited considerable amount of variation for the twenty one characters studied, out of that, nine characters such as days to first pod maturity, branch count per plant, collar girth per plant, pod diameter per plant, pod length per plant, seed length per pod, seed diameter per pod, seed count per pod and hundred (100)seed weight . The high range of values indicated the good scope for selection of suitable basic material for breeders for further crop improvement (Table 2). The exhibited significant differences for the different traits among the tested genotypes were mostly due to genetic factors rather than environmental ones as indicated by the moderately relative genetic variances with a very low environmental variance (Table 2). 


\section{Phenotypic and genotypic coefficient of variability and genetic advance.}

Generally, the phenotypic variance was higher than genotypic variance with a low environmental variance. however, low but with moderately high for days to $50 \%$ flowering, days to first pod maturity environmental variances. However, the phenotypic coefficient of variability and genotypic coefficient of variability were generally moderate for leaf count, plant height at $50 \%$ flowering, pod count, seed diameter, seed yield and dry matter weight. Heritability (broad sense) was generally high for all traits studied. The genetic advance estimate values were moderately high for some traits except for plant height, days to $50 \%$ flowering, days to first pod maturity and pod diameter.

\section{DISCUSSION}

The success of any crop improvement programme depends on an understanding of the nature and degree of interaction played by the genotype with environment on the characters being selected. The exhibited variation in a trait is specified by the phenotypic variance, which includes genetic and environmental components and by a genotype and environment interaction. A fundamental limitation for plant breeders is to determine to what degree or extent the desired traits are heritable and to what extent they are influenced by the environment. This is because selection of desirable genotypes, and consequently plant improvement, will not be possible without genetic variation (Elsiddig et al., 2003).

The mean squares for genotype $x$ location were highly significant for some of the characters studied (Table 1). These highly significant differences for the different traits among the tested genotypes were mostly due to genetic factors rather than environmental ones as indicated by the high genetic variances (Table 2). This implies that the different genotypes will not be consistent in their performance in different environments. These results indicate the importance of GE interactions in determining the expression of these characters, and, moreover, they indicate that selection for a desired genotype is to be made after it is thoroughly tested for more than one year at more than one location (Withanage, 2005; Chattopadhyay et al., 2001; Kulkarni and Birari,1999; Lopes et al., 2000).

The study revealed the phenotypic variance value to be higher than the genotypic variance with low environmental variance(Table 2). This indicates that environmental influences were low compared to genetic factors in the variability observed indicating that the traits have broad genetic base. High heritability coupled with high genetic advance indicates the predominance of additive gene effects, which is the key factor for any selection programme to achieve better results (Panse, 1957; Vange and Ojo, 1997).

\section{CONCLUSION}

The following conclusions can be drawn based on the results finding of this study:-

1 The common bean plant is highly sensitive to environmental factors as indicated by the high significant variation present among the test materials. Therefore selection for a desired common bean genotype is to be made after it is thoroughly tested for more than one year at more than one location.

2 There exist a high levels of genetic variability for the traits under study in the tested material and such genetic variability is very crucial exploitable resource for yield and quality crop improvement programmes.

3 The high heritability values in addition to some high genetic advance values indicates the possible predominance of additive gene effects ( Panse,1957; Vange and Ojo,1997). 
Table 2: Mean Range and Genetic Variability Parameters for twenty traits in phaseolus vulgaris L. accession lines during the 2012 wet season.

\begin{tabular}{|c|c|c|c|c|c|c|c|c|c|}
\hline Traits & Means & Mean Range & $\begin{array}{r}\text { Genotypic } \\
\text { Variance }\end{array}$ & $\begin{array}{l}\text { Phenotypic } \\
\text { Variance }\end{array}$ & $\begin{array}{c}\text { Environmental } \\
\text { Variance }\end{array}$ & $\begin{array}{l}\text { Heritability } \\
\left(h^{2}\right)\end{array}$ & $\begin{array}{c}\text { Genotypic } \\
\text { Coefficient } \\
\text { Variance }\end{array}$ & $\begin{array}{r}\text { Phenotypic } \\
\text { Coefficient } \\
\text { Variance }\end{array}$ & $\begin{array}{l}\text { Genetic } \\
\text { Advance }\end{array}$ \\
\hline $\begin{array}{l}\text { Germination count } \\
\text { Leaf count } \\
\text { Branch count }\end{array}$ & $\begin{array}{r}14.17 \\
25.49 \\
8.235185\end{array}$ & $\begin{array}{r}9.00-14.77 \\
14.40-29.500 \\
5.700-9.767\end{array}$ & $\begin{array}{r}4.97 \\
53.37 \\
2.61\end{array}$ & $\begin{array}{c}5.28 \\
56.26 \\
4.04\end{array}$ & $\begin{array}{l}0.31 \\
2.88 \\
1.43\end{array}$ & $\begin{array}{l}0.94 \\
0.95 \\
0.65\end{array}$ & $\begin{array}{l}15.09 \\
28.66 \\
19.63\end{array}$ & $\begin{array}{l}15.55 \\
29.43 \\
24.41\end{array}$ & $\begin{array}{l}30.16 \\
57.51 \\
32.53\end{array}$ \\
\hline Plant height & 127.9315 & $84.167-146.05$ & 95.29 & 1900.42 & 1805.14 & 0.05 & 7.63 & 34.08 & 3.52 \\
\hline Collar girth & 2.672222 & $2.283-3.300$ & 0.29 & 0.39 & 0.10 & 0.74 & 20.07 & 23.31 & 35.59 \\
\hline Days to first flower & 44.7037 & $40.33-52.833$ & 50.92 & 53.98 & 3.06 & 0.94 & 15.96 & 16.44 & 31.94 \\
\hline Days to $50 \%$ flower & 48.90741 & $43.00-54.500$ & 30.33 & 37.47 & 7.14 & 0.81 & 11.26 & 12.52 & 20.87 \\
\hline Plant height at $50 \%$ Flower & 81.87593 & $20.43-105.483$ & 1264.80 & 1296.40 & 31.60 & 0.98 & 43.44 & 43.98 & 88.38 \\
\hline Days to first pod maturity & 74.5 & $67.667-80.167$ & 24.81 & 46.63 & 21.82 & 0.53 & 6.69 & 9.17 & 10.05 \\
\hline $\begin{array}{l}\text { Peduncle count } \\
\text { Pod count } \\
\text { Pod diameter per plant }\end{array}$ & $\begin{array}{c}17.18519 \\
15.40926 \\
1.157407\end{array}$ & $\begin{array}{r}14.00-23.33 \\
8.583-23.767 \\
1.083-1.417\end{array}$ & $\begin{array}{r}24.05 \\
65.59 \\
0.02\end{array}$ & $\begin{array}{c}33.79 \\
80.37 \\
0.04\end{array}$ & $\begin{array}{c}9.73 \\
14.78 \\
0.02\end{array}$ & $\begin{array}{l}0.71 \\
0.82 \\
0.41\end{array}$ & $\begin{array}{l}28.54 \\
52.56 \\
11.31\end{array}$ & $\begin{array}{l}33.82 \\
58.18 \\
17.62\end{array}$ & $\begin{array}{l}49.61 \\
97.81 \\
14.95\end{array}$ \\
\hline Pod length per plant & 11.80926 & $10.50-13.46$ & 3.69 & 3.90 & 0.22 & 0.94 & 16.26 & 16.73 & 32.56 \\
\hline Seed length per pod & 1.261111 & $1.083-1.50$ & 0.05 & 0.10 & 0.05 & 0.49 & 17.78 & 25.32 & 25.72 \\
\hline Plant count at harvest. & 10.01852 & $6.333-12.50$ & 4.52 & 7.11 & 2.59 & 0.64 & 21.22 & 26.61 & 34.84 \\
\hline Seed diameter per pod & 0.66037 & $0.428-0.880$ & 0.04 & 0.04 & 0.00 & 0.94 & 29.76 & 30.69 & 59.45 \\
\hline Seed count per Pod & 6.655556 & $5.033-8.200$ & 2.19 & 2.25 & 0.07 & 0.97 & 22.21 & 22.56 & 45.04 \\
\hline Pod yield plot & 2170.741 & $1297.7-3000.0$ & 646846.6 & 727353.67 & 80507.00 & 0.89 & & 39.29 & 71.98 \\
\hline Seed yield yield plot & 1873.37 & $1129.5-2852.5$ & 553431.33 & 594303.33 & 40872.00 & 0.93 & $\begin{array}{l}37.05 \\
39.71\end{array}$ & 41.15 & 78.94 \\
\hline 100Seed Weight & 36.7963 & $30.33-51.00$ & 119.33 & 124.86 & 5.53 & 0.96 & 29.69 & 30.37 & 59.79 \\
\hline Dry matter weight & 2129.148 & $1311.8-3084.8$ & 559162.00 & 780167.00 & 221005.00 & 0.7 ; & 35.12 & 41.48 & 61.25 \\
\hline
\end{tabular}




\section{REFERENCE}

Elsiddig,A.A., Abdelwahab. H. Abdalla and Ahmed S. Fadlalla.(2003).Genotypic-Environment Interaction for Yield, Yield Components and Fibre Characteristics in Cotton (Gossypium spp.). U. of K. J. Agric. Sci, 12 (1), 2003.

Adesoye, A. I and Ojobo O. A.(2012). Genetic diversity assessment of Phaseolus vulgaris L. landraces in Nigeria's mid-altitude agroecological zone. International Journal of Biodiversity and Conservation Vol.4(13), pp. 453-460, Available online at http://www.academicjournals.org/IJBC DOI: 10.5897/IJBC11.216 .ISSN 2141-243X (02012.

Anderson, J.W., Smith, B.M and Washno, C.S .(1998). Cardiovascular and renal benefits of dry beans and soybean intake. Am. J. Clin. Nutr. 70(suppl.):464s-474s.

Assady, B., Dorri, H.R and Vaezi, S. (2005). Study of genetic diversity of bean (Phaseolus vulgaris L.) genotypes by multivariate analysis methods. The first Iranian Pluse symposium, research center for plant sciences. Ferdowsi University of Mashhad, Mashhad, Iran. pp: 650

Asuman Kan, Muharrem Kaya, Ay_egül Gürbüz, Arif anli, Kamil Özcan and Cemalettin Ya_ar Çiftçi.(2010). A study on genotype $x$ environment interaction in chickpea cultivars (Cicer arietinum L.) grown in arid and semiarid conditions. Scientific Research and Essays Vol. 5(10), pp. 1164-1171,18 ${ }^{\text {th }}$ May,2010.Available online at http://www.academicjournals.org/SRE ISSN 1992-2248 ( 2010 Academic Journals.

Avav,T and S.A.Ayuba. (2006). FERTILIZERS and PESTICIDES: Calculation and ApplicationTechniques. Jolytta Publication (Printed by LANRAD).\# 154A Gyado Villa, KM3 Gboko Rd, Makurdi.Benue State - Nigeria.

Bazzano LA, He J, Ogden LG, Loria C, Vapputuri S, Myers I and Whelton, P.K. (2001). Legume consumption and risk of coronary disease in U.S men and women. Arch. Int. Med. 161:2528.

Beebe, S.,Ramirez, J., Jarvis, A., Rao, I.M., Mosquera, G., Bueno, J.M and Blair, M.W.(2011a). Genetic improvement of common beans and the challenges of climate change. In: Yadav SS; Redden R; Hatfield JL; Lotze-Campen H; Hall A, eds. Crop adaptation to climate change. Wiley-Blackwell, Oxford, UK.

Chattopadhyay, A., Dasgupta, T., Hazra, P. And Som, M.G. (2001). Phenotypic stability for green pod yield and its components in cowpea (Vigna unguiculata (L.) Walp.). Indian Agriculturist, 45(3-4) : 141-146.

GENSTAT, 2003. GENSTAT Release 4.23 (Copyright, 2003) Lawes Agricultural Trust Rothamsted Experimental Station.

Geil, P.B and Anderson, J.W.(1994). Nutrition and health implications of dry beans: a review. J. Am. Coll. Nutr. 13:549-558.

Hala Adb El-Aal, Nevien El-Hwat,Nabil El-Hefnawy and Mahmoud Medany.(2011).Effect Of Sowing Dates, Irrigation Level and Climate Change on Yield of Common Bean( Phaseolus vulgaris L.).American -Eurasian J.Agric.\& Environ.Sci.,11(1):79-86 2011.ISSN 1818-6769.@ IDOSI Publication, 2011.

Hangen, L and Bennick, M.R. (2002). Consumption of black beans and navy beans ( $P$. vulgaris) reduced azoxymethane-induced colon cancer in rats. Nutr. Canc. 44:60-65.

Heimler D, Vignolini P, Dini, M.G and Romani, A .(2005). Rapid tests to assess the antioxidant activity of Phaseolus vulgaris L. dry beans. J. Agric. Chem. 53:3053-3056.

ICS-Nigeria.(2010).Growing Cowpea in Nigeria: Commercial crop production guide series. Information and Communication Support for Agricultural Growth in Nigeria .www.ics-nigeria.org

Jing, R., Vershinin, A., Grzebyta, J., Shaw, P., Smýkal, P., Marshall, D., Ambose,M.J., Ellis, T.N and Flavell, A.J. (2010). The genetic diversity and evolution of field pea (Pisum) studied by high throughput retrotransposon based insertion polymorphism (RBIP) marker analysis. BMC Evolutionary Biology 10: art.44 [doi:10.1186 /1471-2148-10-44]

Kulkarni, P.J. And Birari, S.P.(1999). Stability studies for green pod yield in asparagus bean. Journal of Maharashtra Agricultural Universities, 24 (3) : 313- 314.

Lyimo, M., Mugula J and Elias, T .(1992). Nutritive composition of broth from selected bean varieties cooked for various periods. J. Sci. Food Agric. 58: 535-539.

Kowal, J. M. and D. T. Knabe. (1972). An Agroclimatological Atlas of the Northern States of Nigeria. Ahmadu Bello University Press, Zaria.

Lopes, A.C. De.A., Freire, Filho, F.R. Queiroz, V. De. Carvalho, R.De, Rocha, M.De, M. De, M.Rocha. M. De, Queiroz, V. De, And Carvalho,R. (2000).Characterization and evaluation of cowpea early maturing genotypes of erect and semi-erect plant types., Revista Cientifica Rural, 5(2) : 86-95.

Norman,M.J.C.,C.J.Pearson and Searle, P.G.E.(1995).Tropical Food Crops: in their environment.2ed.Cambridge University Press.Pp208-224.

Panse, V.G. (1957). Genetics of quantitative characters in relation to plant breeding. Indian J. Genetics and Breeding 17(2): 318-328.

PARK, S.R.(1987). Cultivar By Environment Interactions, Yield Stability And Grouping Of Test Locations For Field Bean Cultivar Trials In Ontario. Can. J. Plant Sci.67:653-659.

Rosa, C.O.B., Costa, N.M.B., Numes, R.M and Leal, P.F.G. (1998). The cholesterol-lowering effect of black beans ( $P$. vulgaris L.) in hypocholesterolemic rats. Arch. Latioam. Nutr. 48:306-310. 
SPSS. (2007). Statistical Package for Social Science. SPSS for Windows. Version 16.0. Chicago, USA. SPSS inc. Released 2007.

Sadeghi,A, Kianoosh Cheghamirza and Hamid, R. D. (2011). The study of morpho-agronomic traits relationship in common bean (Phaseolus vulgaris L.). Article No.: 111115. BIHAREAN BIOLOGIST 5(2): http://biologieoradea.xhost.ro/BihBiol/index.html. pp.102-108

Salehi, M., Tajik M and Ebadi, A.G. (2008). The study of relationship betweendifferent traits in common bean (Phaseolus vulgaris L.) with multivariatestatistical methods. American-Eurasian Journal of Agricultural \&Environmental Science 3: 806-809.

Soleri, D., Smith, S.E. (1995).Morphological and phonological comparisons oftwo Hopi Maize varieties conserved in situ and ex situ. Economic Botany 49:56-77.

Thurling, N.,and Vijendra Das, L.D. (1979). Variation in the pre-anthesis development of spring rape (Brassica napus L.) Aust. J.Agric. Res 28:597-607.

Vange, T. and. Ojo, A.A.( 1997). Variability and Heritability estimates of yield and yield components in some Nigeria lowland rice genotypes. International Rice Research Notes (IRRN) Phillipines, 22: 3. P. 6.

Vijendra Das,L.D.( 2000). Problems Facing Plant Breeding.CBS Publishers \& Distributors.New Delhi-110-002.Pp 122-125.

Wortmann, C.S., Kirkby, R.A., Eledu, C.A. and Allen, D.J. (1998). Atlas of common bean (Phaseolus vulgaris L.) production in Africa, CIAT, Cali, Colombia. 133pp.

Withanage Don Lesly.(2005).Characterization And Evaluation of Cowpea (Vigna Unguiculata [L.] Walp). Germplasm. A Thesis submitted to the University of Agr icultural Sciences, In part ial fulf $i$ llment of the requi rements for theDegree Of Master Of Science (Agriculture) In Genetics And Plant Breeding ,College Of Agriculture, Dharwad University Of Agricultural Sciences,Dharwad - 580 005.November, 2005. 